\title{
IMPACT OF MAHAWELI DIVERSION SCHEME ON BIOLOGICAL DIVERSITY OF DOWNSTREAM FLOOD PLAINS AND ASSOCIATED VILLUS
}

\author{
${ }^{1} \mathrm{~KB}$ Ranawana and ${ }^{2} \mathrm{SP}$ Ekenayake \\ ${ }^{1}$ Department of Zoology Faculty of Science, University of Peradeniya \\ ${ }^{2}$ Natural Resources Management Systems, Environment Division, \\ Mahaweli Authority Damsite, Polgolla
}

Flood plains of Mahaweli River ccver an area of 50,000 hectares. The flood plain extends from the river mouth in Trincomalee at its bottom end, to a little way south of the old settlement of Yakkure situated southwest of Marampitiya in the Polonnaruwa district. The flood plain is composed of various ecological zones consisting of river channels, villus

(Riverine marshes) seasonally flooded grasslands and swamp forest. Villus are shallow and saucer-shaped depressions on grould their water level is maintained by the annual cycle of rainfall and river flooding. Most of these are directly connected to the Mahaweli River by channels. There are 38 identified Yitlus located in the Mahaweli River floodplain system.

A study program was initiated in carly 2000 to evaluate the changes that are taking place in the biotic components of this important ecosystem due to the Mahaweli Development activities such as reservoir construction and water civersion.

Villus and floodplains have direct $o$ indirect connection with the river or its tributaries. When the river is high, water flows into the Villu or floodplains, and when the water level falls the reverse flow may occur towards the river. It was anticipated that upstream diversion schemes of Mahaweli River would reduce the river flow at Manampitiya by $50 \%$. However field investigation carried out during our survey indicated that water levels of the Villus have not changed significantly due to the diversion scheme.

Accelerated Mahaweli program prcvided irrigation water for large areas of undeveloped land around villus, thus converting then in to paddy fields. All These paddy field receive water for both 'Yala' and 'Maha' rice growi $\chi_{\xi}$ seasons. Today, vast extents of paddy fields drains in to Villus of the Mahaweli System. As a result, villus in the Mahaweli flood plain now receive a year-round supply of water. Before the river diversion scheme villus received water from the river only during the flooding senson (i.e. January.) This has brought changes in the water regimes of the villus.

At the moment there is a booming development of Eichhornia crassipes (Japan jabara) due to excessive loading of nutrients in villus.

The study found that the river diversion schemes have resulted considerable changes in the biota of the Villus and other ecosystems associated with the river. Therefore, steps should be taken to release floodwater to Villus during the natural floor period of the river in order to sustain the natural faunistic and floristic diversity in the villus and associated flood plains. 